Article

\title{
An Analysis of Technical Efficiency for Household's Rice Production in Cambodia: A Case Study of Three Districts in Battambang Province
}

\author{
Sokvibol Kea ${ }^{1,2,}$, Hua Li ${ }^{1, *}$ and Linvolak Pich ${ }^{3}$ \\ 1 College of Economics and Management (CEM), Northwest A\&F University, 712100 Shaanxi, China \\ 2 Faculty of Sociology \& Community Development, University of Battambang, 053 Battambang, Cambodia \\ 3 College of Water Resources and Architectural Engineering (CWRAE), Northwest A\&F University, 712100 \\ Shaanxi, China; pichlinvolak@yahoo.com \\ * Correspondence: keasokvibol@yahoo.com (S.K.); lihua7485@163.com (H.L.); Tel.: +855-96-986-6668 (S.K.); \\ +86-133-6393-6398 (H.L.)
}

\begin{abstract}
The aims of this study are to measure the technical efficiency (TE) of Cambodian household's rice production and trying to determine its main influencing factors using the stochastic frontier production function. The study utilized primary data collected from 301 rice farmers in three selected districts of Battambang by structured questionnaires. The empirical results indicated the level of household rice output varied according to differences in the efficiency of production processes. The mean TE is 0.34 which means that famers produce $34 \%$ of rice at best practice at the current level of production inputs and technology, indicates that rice output has the potential of being increased further by $66 \%$ at the same level of inputs if farmers had been technically efficient. Furthermore, between 2013-2015 TE of household's rice production recorded $-14.3 \%$ decline rate due to highly affected of drought during dry season of 2015. Moreover, evidence reveals that land, fertilizer, and pesticide are the major influencing input factors of household's rice production, while disaster, education of household head, family size and other crops' cultivated area are core influencing factors decreasing TE. Conversely, the main influencing factors increasing TE are irrigated area, number of plot area and sex of household head.
\end{abstract}

Keywords: Agricultural productivity, Battambang, Cambodia, Rice production, Stochastic frontier production function (SFA model), Technical efficiency

\section{Introduction}

Food is the basic need of all lives on earth for survival, as well as an instrument of national power for maintaining independence, prestige, and honor of a nation. Food security is not only a key aspect of human development, but also the prime goal of any nations. Ahmad [1] urged that food security in the country is very essential for achieving primary goal of stability of a political government, since no any sensible nations would tolerate food insecurity particularly in the face of mounting population pressure which leads to further widening of already existing disparities.

World population is increasing energetically, from around 6.1 billion in 2000 to more than 7.2 billion in 2014, and expected to reach 9 billion by 2050 [2]. As a result of this rapid growth which is causing threat to food security, there is a need to understand agricultural growth and productivity for increasing agricultural outputs in order to meet the high demand for food. Agriculture remains fundamental in the $21^{\text {st }}$ century for economic growth. According to World Bank [3], agriculture accounts for one-third of gross domestic product (GDP) and three-quarters of employment in Sub-Saharan Africa. Nonetheless, agriculture is more vulnerable to climate change than any other sectors. A warming climate could cut crop yields by more than $25 \%$. Agriculture and land use change are also responsible for $19-29 \%$ of global greenhouse gas emissions [3]. 
Agriculture is the traditional mainstay of the Cambodian economy. It remains as the dominant sector over the country's history. In 1985, agriculture accounted for $90 \%$ of GDP and employed approximately $80 \%$ of the work force [4]. Although contribution of agricultural sector to national GDP have been decreased, growth in agricultural sector still played a crucial role in the development of Cambodia [5]. This sector continues to make a rising contribution to the growth of the Cambodian economy. The sector grew 4.3\% in 2012 and accounted for 4.75 million workers out of a labor force of 8 million in 2011 [6]. Industry, agriculture, and services are three main essential sectors of GDP composition with the share of $24.5 \%, 34.8 \%$, and $40.7 \%$ in 2013respectively [7].

Rice cultivation stands as the most essential segment of Cambodian agricultural sector and plays a major role in the national economic growth (contributing to $15 \%$ of the national GDP). It is not only the most important food crop playing an unprecedented role in combating food insecurity for the nation, but also a key production economic crop. The production of rice is the most organized food production system in the country, occupies more than $80 \%$ of total cultivated land and is the most essential exported agricultural commodities [8]. Rice farming has an important role as a sector producing staple food for almost all of the population and provides a livelihood for millions of people in rural areas. Moreover, the value-chain of rice is one of the four major mainstays of Cambodian economy, along with textile, tourism and the construction industry. Unfortunately, the exportable surplus of Cambodian rice (3-4 million tons a year) are processed in Vietnam or Thailand today, which represents an important loss in terms of added-value for the sector [9].

Rice is the "White Gold» for Cambodian people. The Royal Government of Cambodia (hereafter, RGC) has declared that supporting the development of the national rice value-chain is one of its first priorities. With the strongly support from RGC, rice production has grown rapidly since 2003, which has firmly changed the country's position from rice deficit to surplus [10]. Nevertheless, growth of rice production in Cambodia has decelerated since 2012 and given the land area constraint, its recovery will depend from now on more on increases in rice productivity and quality than on area expansion [11]. Therefore, productivity and efficiency use of existing resources might be another source of rice development potential in Cambodia. Nevertheless, although significant productivity gains have been achieved in the country since the end of the conflict, the average rice yield still remains below those reached by neighboring countries (like Thailand and Vietnam).

In the recent years, although the studies of productivity and efficiency have been taken the attention of most economists and policy makers around the world [12], agricultural productivity and efficiency studies (particularly, rice production efficiency studies) in Cambodia still seem to be very rare. Thus, only research works conducted by the related government agencies, such as Ministry of Agriculture, Forestry and Fishery (MAFF), National Institute of Statistics (NIS), Cambodia Development Resource Institute (CDRI), Cambodia Agricultural Research and Development institute (CARDI), etc. could be found these days, while the studies of the scholars still remains identical infrequently to see. Given the scarcity of literature on efficiency in Cambodia, the study consequently seeks to supplement literature and contribute in many ways to bridge the gap and supplement the shortage.

This study attempts to contribute to the productivity literature of the agriculture of developing countries by exploring the distribution of technical efficiency (hereafter, TE) among rice production households operating in the northwest region of Cambodia which is the high potential region for rice production -- specifically, Battambang province. The aims of this study are to measure the TE of Cambodian farmers' rice production, and trying to determine its main influencing factors for explaining the possibilities of increasing productivity of rice, which might be the useful information for rice producers as well as policy makers of the government and related parties, in order to improve Cambodian rice production for sustainable economic and social development at large. 
The rest of this paper is organized as follows: Section 2 demonstrates the methodology and analytical frameworks used in the study. Section 3 presents sources of data and descriptive statistics of input and output variables as well as variables of rice production TE's influencing factors, while the results are presented and discussed in Section 4. Finally, conclusion remarks are given in Section 5 .

\section{Research Methodology}

Theoretically, productivity is the ratio of the output(s) that it produces to the input(s) that it uses [13]. Hence, agricultural productivity is measured as the ratio of agricultural output(s) to agricultural input(s). Efficiency, alternatively, is defined as the level of operation that produces the greatest amount of output(s) with the lowest amounts of input(s). Efficiency relates to the use of all inputs, for instance labor, natural resources, money, time, etc. in producing any given output(s). It is the main factor to determine productivity. Efficiency score range between 0.00 and 1.00 . The maximum score (1.00) represents the highest efficiency while the scores of 0.00-0.99 show a firm's inefficiency, indicating the relative displacement from the frontier ${ }^{1}$ [15]. Most references to the concept of efficiency are based directly or indirectly on Farrell [16] which states that "the efficiency can be measured in relative terms as a deviation from best practices of producers compared with producer groups". The production process is technically efficient if and only if the maximum quantity of output(s) can be achieved for a given quantity of input(s) and technologies [17]. More importantly, Farrell [16] also suggested to measure technical efficiency by estimating frontier production function.

Technical efficiency (TE) is measured as the ratio between the observed output(s) to the maximum output(s) under the assumption of fixed input(s) which called output-oriented TE "OO", or, alternatively, as the ratio between the minimum input(s) to the observed input(s) under the assumption of fixed output(s), i.e. called input-oriented TE "IO" $[13,16]$. There are some basic differences between the OO and IO models as features of the technology are concerned, see further details in [13] and [18]. Furthermore, TE in production is defined as the ability of the producer (i.e. firm, factory, or farmer) to produce at the maximum output (frontier production) at the given quantities of inputs and production technology [19]. Production efficiency is concerned with the relative performance of the process used in transforming input(s) into output(s). The analysis of efficiency is generally associated with the possibility of farms producing a certain optimal level of output(s) from a given bundle of resources or certain level of output(s) at least-cost. The greater the ratio of production output(s) to the factor input(s), the greater the magnitude of TE and vice versa [20]. This definition of TE points toward differences in TE between farms exist. Variation in TE of producers might arise from managerial decisions and specific-farm characteristics that affect the ability of the producer to adequately use the existing technology.

The present study implement the stochastic frontier production function (hereafter, SFA model), which is originally and independently proposed by Aigner, Lovell [19], and Meeusen and Van den Broeck [21] for measuring the technical efficiency (TE) of Cambodian household's rice production in the northwest region. The study applied FRONTIER version 4.1c [22] which is the most commonly used package for estimation of SFA model with the logarithmic form of translog production function for the analysis of TE. Coelli [22] had developed the software FRONTIER 4.1c, which can be used to generate both the stochastic production frontier and the inefficiency model simultaneously. Moreover, the FRONTIER 4.1c was widely applied in different fields of research in the recent years, especially in agricultural studies like [15, 17, 20, 23-28] for instance.

\footnotetext{
1 According to $14 . \quad$ Coelli, T.J., Recent Developments in Frontier Modeling and Efficiency Measurement. Australian Journal of Agricultural Economics, 1995. 39(3): p. 219-245. "Frontier" refers to a bounding function, which provided benefits of heavily influencing of the best performing firms in a field (of economics), that always reflect the technology they are using. Additionally, the frontier function represents a best-practice technology against which the efficiency of firms within the industry can be measured.
} 
The technical efficiency of $i^{\text {th }}$ household, $T E_{i t}$, can be estimated by the ratio of observed output for $i^{\text {th }}$ household, $y_{i t}$, relative to the potential output defined by SFA model, $f\left(x_{i t}\right)$, as follow:

$$
T E_{i t}=y_{i t} / f\left(x_{i t}, t\right)=\exp \left(-u_{i t}\right) \leq 1
$$

Technical efficiency changes (hereafter, TEC) of $i^{\text {th }}$ household between period $t$ and $t+1$ are measured as the ratio of one household's efficiency scores in period $t+1$ to its efficiency scores in period $t$, which can be expressed as the following formula:

$$
T E C_{i}^{t, t+1}=T E_{i}^{t+1} / T E_{i}^{t}
$$

According to Aigner, Lovell [19] and Meeusen and Van den Broeck [21], the general form of the stochastic frontier production function model can be expressed as:

$$
\operatorname{Lny} y_{i t}=\operatorname{Lnf}\left(x_{i t}, t ; \beta\right)+v_{i t}-u_{i t}
$$

where $y_{i t}$ and $x_{i t}$ are output and input vector of rice production of $i^{\text {th }}$ household in the sample within period $t$ respectively; $L n$ indicates the natural logarithm function form; $\beta$ represent the estimated coefficients; $v_{i}$ is two-side random error term which represented statistical noise assumed to be normal distribution, $v_{i} \sim N\left(0, \sigma_{v}^{2}\right) ; u_{i}$ denotes technical inefficiency, which is one-side error term that assumed to be independent to $v_{i t}$ with half-normal distribution ${ }^{2}, u_{i t} \geq 0$, $u_{i} \sim\left|N\left(0, \sigma_{u}^{2}\right)\right| ; v_{i}$ and $u_{i}$ are independent; $i=1,2, \ldots \ldots, N ; N$ is number of total samples, and $t$ is time variable measured as year, $t=1,2, \ldots, T$.

Translog production function form of SFA model can be written as:

$$
\operatorname{Lny}_{i t}=\beta_{0}+\sum_{j} \beta_{j} \operatorname{Lnx} x_{j i t}+\beta_{t} t+\frac{1}{2} \sum_{j} \sum_{k} \beta_{j k} \operatorname{Lnx} x_{j i t} \operatorname{Lnx} x_{k i t}+\frac{1}{2} \beta_{i t} t^{2}+\sum_{j} \beta_{j t} \operatorname{Lnx} x_{j i t} t+v_{i t}-u_{i t}
$$

where $x_{j i}$ is rice production input $j^{\text {th }}$ of $i^{\text {th }}$ household in the sample; $J$ is number of inputs variables; $\beta_{0}, \beta_{j}$ and $\beta_{t}$ represent estimated coefficients; $v_{i t}$ and $u_{i t}$ are the same as above notation.

The technical inefficiency (TI) model for rice production of $i^{\text {th }}$ household, $u_{i t}$, can be expressed in following general form:

$$
u_{i t}=\delta_{0}+\sum_{k=1}^{n} \delta_{k} z_{k i t}+\omega_{k i t}
$$

where $u_{i t}$ is the inefficiency effects that could be estimated by 2-stage estimation technique in FRONTIER 4.1c extemporaneously; $\omega_{k i t}$ is the stochastic noises; $z_{k i t}$ denotes exogenous variables that are factors affecting the households' rice production technical efficiency scores; $\delta_{0}$ represents the intercept term; $\delta_{\mathrm{k}}$ is the parameter for $k^{\text {th }}$ independent variables to be estimated; if $\delta_{k}$ is negative indicates positive relationship between affecting factor variables and the efficiency scores, conversely, if $\delta_{k}$ is positive shows negative relationship between the efficiency scores and affecting factors.

The parameters estimation of SFA model can be achieved by applying Maximum-Likelihood (ML) estimation method, which estimates the likelihood function in terms of two variance parameters, see Coelli [31]:

$$
\gamma=\sigma_{u}^{2} / \sigma_{s}^{2} ; \sigma_{s}^{2}=\sigma_{v}^{2}+\sigma_{u}^{2}
$$

Gamma $(\gamma)$ takes value between zero and one $(0 \leq \gamma \leq 1)$, reflects validity of the random disturbances $\left(v_{i}, u_{i}\right)$ proportion (shows the share of inefficiency in the overall residual variance). If $\gamma$ is equal to zero, it means that all variations of the production are due to noises. If $\gamma$ is closer to zero, it indicates that the gap between actual output and the maximum possible output mainly comes from other uncontrolled pure random factors, which makes the use of stochastic frontier

\footnotetext{
2 The assumption can be replaced by other assumption as well, such as truncated-normal 29. Stevenson, R.E., Likelihood Functions for Generalized Stochastic Frontier Estimation. Journal of Econometrics, 1980. 13: p. 57-66, 30. Battese, G.E. and T.J. Coelli, Frontier production functions, technical efficiency and panel data, With application to paddy farmers in India. The Journal of Productivity Analysis, 1992. 3: p. 153-169.
} 
production function model meaningless. In contrast, if $\gamma$ is closer to one, it shows that the gap comes mainly from the effects of one or more exogenous variables $z_{k i}$, indicates using stochastic frontier production function model is more appropriate. And if it is equal to one, then it means that all variations are due to technical inefficiency $[13,32]$.

\section{Data and Descriptive Statistics}

To allow the estimation of rice's TE at household-level, primary data were collected from a random sample of 301 rice production households from 10 communes (equal to 30 villages) in three selected districts of Battambang province by using structured questionnaires. The district of Thmar Koul, Moung Russei, and Sangkhae were purposively selected as the study areas, based on their total rice production area and total number of farmers with rice farming as primary occupation (hereafter, rice farmers) in 2014, which ranked from the first to the third among all 14 districts of Battambang province (i.e. the rice bowl of Cambodia). The field surveys were conducted in February and December of 2015 for gathering 3-years data of households' rice production (2013, 2014 and 2015). Structured questionnaire designed to capture information related to the characteristics of rice farmers, their inputs allocated to the rice cultivation and its output(s). Furthermore, the collected primary data were supplemented with secondary data collected from various relevant sources.

The SFA model was constructed by one output variable (i.e. production quantity of rice) and five input variables included land, labor, fertilizer, pesticide, and other capital. Output variable measured as the total quantity of un-milled rice produced by individual households within the year or the sum of rice output produced both in wet season and dry season by households (hereafter, household rice output), unit in kilograms $(\mathrm{kg})$. Land input was the total area of rice actually harvested within the year, measured in hectares (ha). In agriculture, land always plays as an important input in production of (agricultural) crops, particularly rice. Farmers who harvested larger land of rice tend to be able to produce higher amount of rice output than the farmers harvested on smaller land. Harvested area (i.e. land input), hence, was expected to have positive effect on total household rice output. Labor input, on the other hand, measured as total annual working days of adult family members (18-65 years old) on the rice field(s) included both male(s) and female(s), unit in days per person per year. In many developing countries, labor input tended to have negative relationship with household rice output since there were plenty of unskilled and low productivity labors existing, unskilled labors always spend higher (longer) time than more productive labors to produce the same level of output. Farmers in Cambodia, however, still seemed to be the lower productive farmers, since most of them were not well educated yet. Thus, in the present study farmers were expected to spend over need of times in rice production. Therefore, labor input was expected to have negative effect on household rice output. Furthermore, fertilizer input measured as total amount of chemical and organic fertilizers' quantity using by households in their rice production annually (unit in $\mathrm{kg}$ ), while pesticide input also measured as total amount of poisons for insects and grass's quantity (for both chemical and organic poisons) using by households, unit in $\mathrm{kg}$. These two input variables were expected to be positively related to household rice output as followed by the concept of green revolution [33]. Additionally, another input variable was determined as the variable of other capital investment on rice production, included investments on agricultural machineries, seeds, and other rental expenses within the year, measured as sum of depreciation of agricultural machineries (i.e. tractors, walking tractors or koryons, pumping machines, pesticide prayers) owned by households, altogether with total expenses on seeds purchasing and other rentals such as wage paid for labors or equipment rentals during various stages of rice production (like plowing, seeding, transplanting, irrigating, harvesting, threshing, as well as transporting), measured in the US dollar (USD). Annual depreciation of machinery was calculated as the division of its bought price by expected usage life (of machineries). Expected usage life of tractors, walking tractors (or koryons), pumping machines, and pesticide prayers, were assumed to be 15 years, 10 years, 5 years and 5 years respectively in the present study according to observations from farmers in the study area. The variable of other capital investment was also expected to have positive effect on household rice output also, as farmers with more capital investment were believed to be able to generate higher 
opportunities for improving their rice production rather than farmers with lower available capital (for investment in their household's rice production). Table 1 provides the summary statistics of the output and inputs of households' rice production in three districts of Battambang province (i.e. Thmar Koul, Moung Russei, and Sangkhae district) from 2013 to 2015.

Output quantity of households' rice production in Battambang was higher in 2014 than 2013 which increased $8.5 \%$ in average from 16.7 thousand kilograms to 18.1 thousand $(\mathrm{kg})$. Nevertheless, household rice output has been decreased by $6.5 \%$ between 2013 and 2015 as the results caused by natural disasters occurred in wet season of 2014 (flood) and dry season of 2015 (drought) which reduced rice output to 15.6 thousand $\mathrm{kg}$ per household (in 2015). Rice area harvested by farmer households (in Battambang) ranged from the smallest of 1 ha to the largest of 82 ha annually. During the study period, in average farmers harvested around 7 ha (included for both wet season and dry season) in 2013, and increased by $1.2 \%$ to 7.1 ha in 2014 . However, average households' rice harvested area in 2015 has been slightly reduced to 7.05 ha. Furthermore, average annual working days of adult family members (18-65 years old) for both male(s) and female(s) on the rice field(s) was 108 days per person in 2013, and increased to 110.5 days in 2014, then reduced to 106.7 days in 2015 . Total quantity of chemical and organic fertilizers using by households in rice production (i.e. fertilizer input), on the other hand, increased by $2.5 \%$ between 2013 and 2015 from average of $772 \mathrm{~kg}$ (2013) to $791 \mathrm{~kg}$ (2015), while pesticide input which measured as total quantity of poisons for insects and grass (both chemical and organic) using by households in rice production also increased by $1.6 \%$ between the same period, from $70.8 \mathrm{~kg}$ to $72 \mathrm{~kg}$ in average. Conversely, during the study period the level of households' other capital investment showed the impressively deduction by $4 \%$, particularly between 2014 and 2015 (other capital input decreased by 12.6\%), indicated the farmers' response to effects of natural disasters that reduced availability of rice area to be harvested.

Table 1. Output and input summary statistics for households' rice production in Battambang province of Cambodia, 2013-2015

\begin{tabular}{|c|c|c|c|c|c|c|}
\hline \multirow[t]{2}{*}{ Variables } & \multicolumn{2}{|c|}{2013} & \multicolumn{2}{|c|}{2014} & \multicolumn{2}{|c|}{2015} \\
\hline & Mean & S.E. & Mean & S.E. & Mean & S.E. \\
\hline \multicolumn{7}{|l|}{ Output } \\
\hline Rice quantity ${ }^{1}(\mathrm{~kg})$ & $16,651.16$ & $1,244.43$ & $18,065.78$ & $1,422.06$ & $15,569.77$ & $1,235.43$ \\
\hline \multicolumn{7}{|l|}{ Inputs } \\
\hline Land 2 (ha) & 6.99 & 0.53 & 7.07 & 0.53 & 7.05 & 0.52 \\
\hline Labor ${ }^{3}$ (days) & 108.27 & 5.58 & 110.45 & 5.66 & 106.69 & 5.32 \\
\hline Fertilizer $^{4}(\mathrm{~kg})$ & 771.73 & 55.02 & 792.09 & 55.98 & 790.72 & 55.87 \\
\hline Pesticide 5 (kg) & 70.84 & 6.64 & 72.03 & 6.75 & 71.95 & 6.70 \\
\hline Other capital ${ }^{6}$ (USD) & 857.18 & 59.49 & 879.05 & 59.31 & 823.37 & 55.72 \\
\hline
\end{tabular}

Source: Calculated by Ms. Office Excel 2016, "S.E" = Standard Error, ${ }^{1}$ Rice output quantity measured as the total quantity of un-milled rice produced by individual households within the year or the sum of rice output produced in both wet season and dry season by households, unit in kilograms (kg). ${ }^{2}$ Land was the total area (both in wet season and dry season) of rice actually harvested within the year, unit in hectares (ha). ${ }^{3}$ Labor measured as total annual working days of adult family members (18-65 years old) on the rice field(s) included both male(s) and female(s), unit in days per person per year. ${ }^{4}$ Fertilizer measured as total quantity of chemical and organic fertilizers using by households in rice production annually (in $\mathrm{kg}$ ). ${ }^{5}$ Pesticide measured as total quantity of poisons for insects and grass (both chemical and organic) using by households, in kg. ${ }^{6}$ Other capital: refer to other capital investment in household's rice production, included investments on agricultural machineries, seeds, and other rental expenses within the year, measured as sum of depreciation of agricultural machineries (i.e. tractors, walking tractors or koryons, pumping machines, pesticide prayers) owned by households, altogether with total expenses on seeds purchasing and other rentals such as wage paid for labors or equipment rentals during various stages of rice production (like plowing, seeding, transplanting, irrigating, harvesting, threshing, as well as transporting), unit in the US dollar (USD). 
Figure 1 illustrates the percentage changes of output and input statistics of rice production of farmer households in three selected districts of Battambang for the periods 2013-2014, 2014-2015, and 2013-2015. The percentage changes within output and input variables from year to year indicated that entire inputs had been increased from 1\% to $2.6 \%$ between 2013 and 2014 which leaded household rice output to increase by $8.5 \%$. However, between 2014 and 2015 all inputs used by households tended to decrease (particularly in labor and other capital input which decreased by $6.8 \%$ and $12.6 \%$ respectively) due to effects of natural disasters in the recent years, caused household rice output to decrease greatly by almost 30\% compared to the production of 2014 .

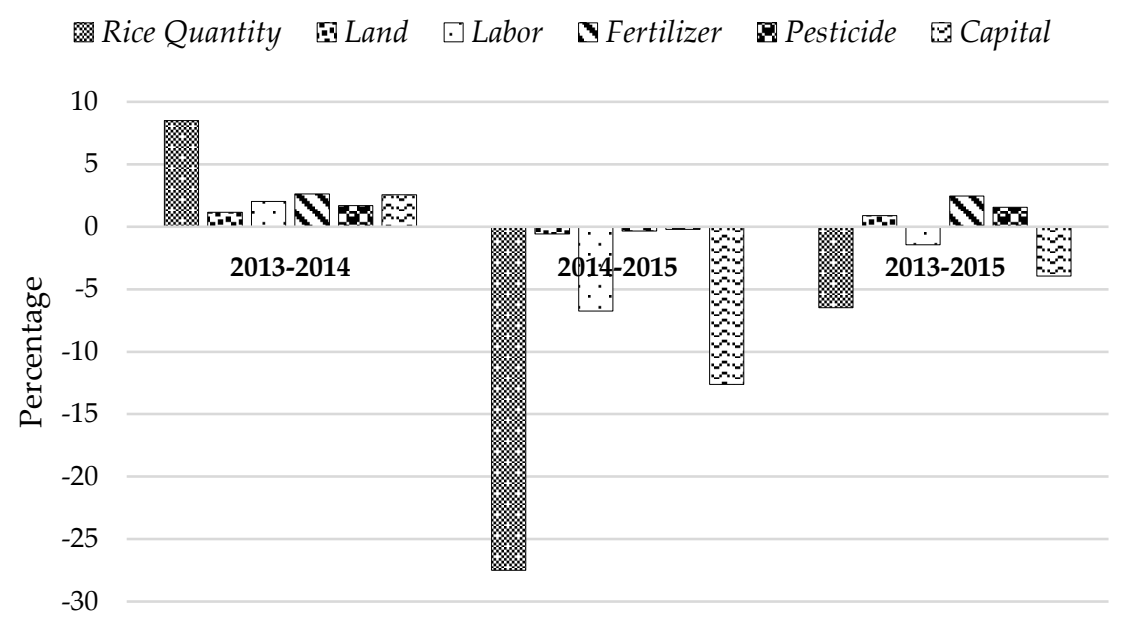

Figure 1. Percentage changes in output and input statistics for households' rice production in Battambang for the periods 2013-2014, 2014-2015, and 2013-2015

In the technical inefficiency (TI) model, there were twelve influencing factors $\left(\mathrm{z}_{\mathrm{kit}}\right)$ of household's rice production TE to be considered in the present study. $z_{1 i t}$ is the age of household head (years old). The age of household head might indicate the possibility of a given rice farmers (younger or older) to adopt innovation (such as new ideas and techniques) in rice cultivating. This variable is also a proxy for experience which represents human capital, revealing that farmers with more years of experience in farming will have more technical skills in management and thus higher efficiency than younger farmers [20]. Nevertheless, rice production in Cambodia still seems to be labor-intensive, which most works in rice cultivation often depends on man-power rather than machineries. Thus, farmers with older age tended to have lower body strength (man-power) than younger farmers. $\mathrm{z}_{2 \mathrm{it}}$ represents household head's sex is the gender dummy variable of household head which value of zero if household head is male and one if female. $z_{3 i t}$ is the education level of household head, i.e. the education dummy variable with value of one if household head is illiterate, two if has primary school education, three if has secondary school education, four if has high school education, five if has bachelor education, six if has graduated education (Master or Ph.D.), seven for other type of education, such as vocational training or informal education system. Both education and age (which proxy for farming experience) are important variables that help to improve the managerial ability of the farmer [34]. $\mathrm{z}_{4 \mathrm{it}}$ represents family size, is the variable of the total number of family members in the household (persons). $z_{5 i t}$ denotes female labor, is the total number of female family member in the household age between 18-65 years old (persons). $\mathrm{z}_{6 \mathrm{it}}$ is the other crops' cultivated area, i.e. the total production area of other crops beside rice, such as corn, sugarcane, cassava, cucumber, pepper, wax melon, bitter melon, bean, eggplant, and other vegetables, measured in square meters $\left(\mathrm{m}^{2}\right)$. $\mathrm{z}_{7 \mathrm{it}}$ is the irrigated areas measured as the percentage of rice production land located near water sources or benefited from irrigation systems to total annual cultivated land of rice. $\mathrm{z}_{8 \mathrm{it}}$ symbolizes the distance to water sources, is the distance of rice production land from the nearest water sources dummy variable with value of zero if production land is near $(0-1 \mathrm{~km})$, one if 1-2 km, two if 2-3 km, three if $3-4 \mathrm{~km}$, four if $4-5 \mathrm{~km}$, five if the production land is far $(\geq 5 \mathrm{~km}) \cdot \mathrm{z}_{9 \mathrm{it}}$ represents the distance to district is 
the variable of distance from the village to the district center, in kilometers $(\mathrm{km}) . \mathrm{z}_{10 \mathrm{it}}$ is the number of plot area, i.e. the total number of plot lands owned and cultivated rice crops by farmer households. $\mathrm{z}_{11 \text { it }}$ denotes the number of cultivation per year, is the number of annual cultivation times that farmers can cultivate their rice crops (times). Disaster is symbolized by $\mathrm{z}_{12 \mathrm{it}}$, is the dummy variable with the value zero if the farmers' rice fields did not affect by floods, droughts, or insects during the study period, and one if farmers' rice fields affected by floods, droughts, or insects.

Table 2. Descriptive statistics of technical inefficiency model's parameters, 2012-2015

\begin{tabular}{|c|c|c|c|c|c|c|}
\hline \multirow{2}{*}{ Variables } & \multicolumn{2}{|c|}{2013} & \multicolumn{2}{|c|}{2014} & \multicolumn{2}{|c|}{2015} \\
\hline & Mean & S.E. & Mean & S.E. & Mean & S.E. \\
\hline Household head's age ${ }^{1}$ & 47.39 & 0.69 & 48.39 & 0.69 & 49.39 & 0.69 \\
\hline Household head's sex ${ }^{2}$ & 0.17 & 0.02 & 0.17 & 0.02 & 0.17 & 0.02 \\
\hline Household head's education ${ }^{3}$ & 2.33 & 0.05 & 2.33 & 0.05 & 2.33 & 0.05 \\
\hline Family size ${ }^{4}$ & 5.16 & 0.11 & 5.17 & 0.11 & 5.17 & 0.11 \\
\hline Female labor (18-65yr) ${ }^{5}$ & 1.63 & 0.05 & 1.63 & 0.05 & 1.63 & 0.05 \\
\hline Other crops' cultivated area 6 & 485.02 & 241.36 & 247.14 & 106.52 & 247.14 & 106.52 \\
\hline Irrigated areas ${ }^{7}$ & 16.82 & 1.22 & 17.35 & 1.23 & 17.30 & 1.24 \\
\hline Distance to water sources ${ }^{8}$ & 2.91 & 0.14 & 2.91 & 0.14 & 2.91 & 0.14 \\
\hline Distance to district 9 & 15.89 & 0.43 & 15.89 & 0.43 & 15.89 & 0.43 \\
\hline Num. of plot area 10 & 1.48 & 0.04 & 1.52 & 0.04 & 1.52 & 0.04 \\
\hline Num. of cultivation per year 11 & 1.44 & 0.03 & 1.44 & 0.03 & 1.44 & 0.03 \\
\hline Disaster ${ }^{12}$ & 0.06 & 0.01 & 0.07 & 0.01 & 0.74 & 0.03 \\
\hline
\end{tabular}

Source: Estimated by Ms. Office Excel 2016. “S.E”: Standard Error. ${ }^{1}$ Household head's age: is the age of household head in years old. ${ }^{2}$ Household head's sex: is the gender dummy variable of household head which value of zero if household head is male and one if female. ${ }^{3}$ Household head's Education: is the education dummy variable with value of one if household head is illiterate, two if has primary school education, three if has secondary school education, four if has high school education, five if has bachelor education, six if has graduated education (Master or Ph.D.), seven for other type of education, such as vocational training or informal education system; ${ }^{4}$ Family size: is the variable of the total number of family members in the household; ${ }^{5}$ Female labor: is the total number of female family member in the household age between 18-65 years old. ${ }^{6}$ Other crops' ${ }^{\prime}$ cultivated area: is the total production area of other crops beside rice i.e. corn, sugarcane, cassava, cucumber, pepper, wax melon, bitter melon, bean, eggplant, and other vegetables, measured in square meters $\left(\mathrm{m}^{2}\right) .{ }^{7}$ Irrigated areas: is the percentage of rice production land located near water sources or benefited from irrigation systems to total annual cultivated land of rice. ${ }^{8}$ Distance to water sources: is the distance of rice production land from water source dummy variable with value of zero if production land is near $(0-1$ $\mathrm{km}$ ), one if $1-2 \mathrm{~km}$, two if $2-3 \mathrm{~km}$, three if $3-4 \mathrm{~km}$, four if $4-5 \mathrm{~km}$, five if the production land is far ( $\geq 5$ $\mathrm{km}) .{ }^{9}$ Distance to district: is the distance from the village to the district center, in kilometers $(\mathrm{km})$. ${ }^{10}$ Number of plot area: is the total number of plot lands owned and cultivated rice crops by farmers. ${ }^{11}$ Number of cultivation per year: is the number of annual cultivation times that farmers can cultivate their rice crops. ${ }^{12}$ Disaster: is the dummy variable with the value zero if the farmers' rice fields did not affect by floods, droughts, or insects during the study period, and one if farmers' rice fields affected by floods, droughts, or insects.

Descriptive statistics of rice production technical inefficiency (TI) model's parameters between 2012 and 2015 are given in Table 2. Most of variables remain insignificant changed between this three years period. The overall statistics reveal that the average age of household's head was 49.4 years old in 2015 ranged from 21 to 83 years old, in which 17\% were female household head. Moreover, the average education level was 2.33, indicating that most of rice farmers' household head just only giant education at secondary school (i.e. grade 7-9) in Cambodian education system. The results also reveal that average family size of rice farmers in Battambang province is about 5.17 
persons per household (ranged from 2 to 12 persons per household), presenting the general figure of rice farmers in the rural Cambodia nationwide. Additionally, female labor (age between 18 and 65 years old) existing in Battambang's rice households during the study period in average was about 1.63 persons per household.

The total cultivated area under other crops beside rice such as corn, sugarcane, cassava, cucumber, pepper, wax melon, bitter melon, bean, eggplant, and other vegetables, was about 485 square meters $\left(\mathrm{m}^{2}\right)$ in average in 2013. Conversely, this amount had been decreased (by almost 50\%) to $247 \mathrm{~m}^{2}$ in 2014 and 2015. Furthermore, irrigated areas, which is the percentage of rice production land located near water sources or benefited from irrigation systems to total annual cultivated land of rice, was about $16.8 \%$ in 2013 average, and had been increased to $17.35 \%$ in 2014 . Water shortage in 2015, nonetheless, had been leading this percentage to decrease a little bit to $17.3 \%$ (in average). These percentages disclose the lack of irrigation facilities and water management policies, since almost $85 \%$ of farmers' rice cultivated areas still not benefit from irrigation systems and remain as rain-fed agricultural lands that are very vulnerable to the global climate change. In average, rice production lands of rural farmers in Battambang located around $2.91 \mathrm{~km}$ from the nearest water sources (or the nearest irrigation systems). This distance is quite far and often causes inability for farmers to use water from existing water sources and irrigation systems. Likewise, the results also show that only $39 \%$ of farmers' rice fields that located less than $1 \mathrm{~km}$ from water sources (or the nearest irrigation systems), thus, other more than $60 \%$ of rice fields still located far from the water sources. Distance to district, on the other hand, measured as the distance from the village to the district center in kilometers, is the proxy variable of farmers' accessibility to information sources (related to rice production such as price information, as well as adoption of new production techniques). Within the study areas, most villages located in average of $15.9 \mathrm{~km}$ from the center of district (ranged from $1 \mathrm{~km}$ to $28 \mathrm{~km}$ ).

Rice farmers in Battambang in average cultivated on 1.48 plot lands (in 2013), and increased to 1.52 in 2014 and 2015. The statistics reveal that around 63\% of farmers cultivated on only one plot land of rice (during the study period). Furthermore, there are only $44 \%$ of farmers who able to cultivate rice crops more than once per year. More importantly, between 2013 and 2014, only 6 to 7\% of rice farmers reported the affecting by natural disasters (i.e. droughts, floods, and insects) on their rice fields. Nevertheless, in 2015, almost $75 \%$ of famers' rice fields had been reported affecting by natural disasters, particularly the drought during 2015's dry season.

\section{Results and Discussions}

\subsection{The rice bowl of Cambodia}

"The rice bowl of Cambodia" is the moniker of a well-known leading rice-producing province of the kingdom, Battambang province, which was founded in the $11^{\text {th }}$ century by the Khmer Empire ${ }^{3}$. "Battambang" literally means "Loss of staff" in Khmer language, referring to the local legend of Preahbat Dambang Kranhoung. The province located in the far northwest bordering by Banteay Meanchey province to the north, Pursat to the east and south, Siem Reap to the northeast, and Pailin to the west. The northern and southern extremes of the province's western boundaries form part of the international border with the Kingdom of Thailand. Furthermore, Tonle Sap Lake (or the Great

\footnotetext{
3 The Khmer Empire was a powerful state in Southeast Asia, formed by Khmer people, lasting from 802 CE to 1431 CE. At its peak, the empire covered much of what today is Cambodia, Thailand, Laos, and southern Vietnam. Using the city of Angkor as capital, the Khmer empire expanded its territorial base mostly to the north (entering the Khorat plateau) and the west, to the Chao Phraya basin and beyond. To the east outcomes were different: several times the Khmer fought wars against two neighboring peoples with powerful kingdoms, the Cham (in today's central Vietnam) and the Vietnamese (in today's northern Vietnam). Despite some victories, as in 1145 CE, when Cham's capital Vijaya was taken, the empire was never able to annex those lands. Conversely, Chams and Vietnamese enjoyed some victories of their own, the most spectacular of which was Cham's humiliating revenge, looting Angkor (1177 CE) and pushing the empire to the edge of destruction 35.

Plubins, R.Q. "Khmer Empire" Ancient History Encyclopedia. 2016 March 12, 2013 [cited 2016 October 8, 2016]; Available from: http://www.ancient.eu/Khmer_Empire/..
} 
Lake) forms part of the northeastern boundary between Siem Reap and Pursat (see Figure 2). In the $18^{\text {th }}$ century, the provincial capital "Battambang city" was established as an important trading city with around 2,500 residents. The city today is the main hub of the northwest connecting the entire region with Phnom Penh and Thailand, and as such it's a vital link to Cambodia. This province is currently subdivided into 14 districts (equal to 96 communes and 818 villages).

With the population of 1.2 million, Battambang was the third populous province in 2015 after the capital city "Phnom Penh" and Kandal province. Average annual population growth rate between 2011 and 2015 was about 2.2\%, while the mean value of female-male ratio between this period was 100.53, indicated that Battambang has more female population rather than male. This was not the surprising statistic for most provinces in Cambodia where the population of females exceeds males, which was one of numerous results caused by the two decades civil war of Cambodia within the past 30 years that voluminous Cambodian people have been killed, particularly male populations. In 2015, number of the total household in Battambang was almost 260 thousand (households) and $13.53 \%$ was leading by female. Although this percentage has been decreased from $14.35 \%$ in 2011, it still seems to be relatively high among provinces of Cambodia. In most cases, female household heads were expected to have lower productivity as well as lower efficiency (rather than male household heads) in the role of family management, particularly rice production families which often required the strength of man-power as an important factor of production. Additionally, mean average of family size in Battambang between 2011 and 2015 was about 4.8 persons per household, illustrates the common figure for families in Cambodia. Likewise, the provincial main labor forces i.e. population age between 18 and 60 years old in average accounted for only $51.6 \%$ between this 5-years period, while the young population age below 18 accounted for almost $40 \%$, and the old population age over 60 years old $9 \%$. Table 3 presents the demographical information of Battambang province between 2011 and 2015.

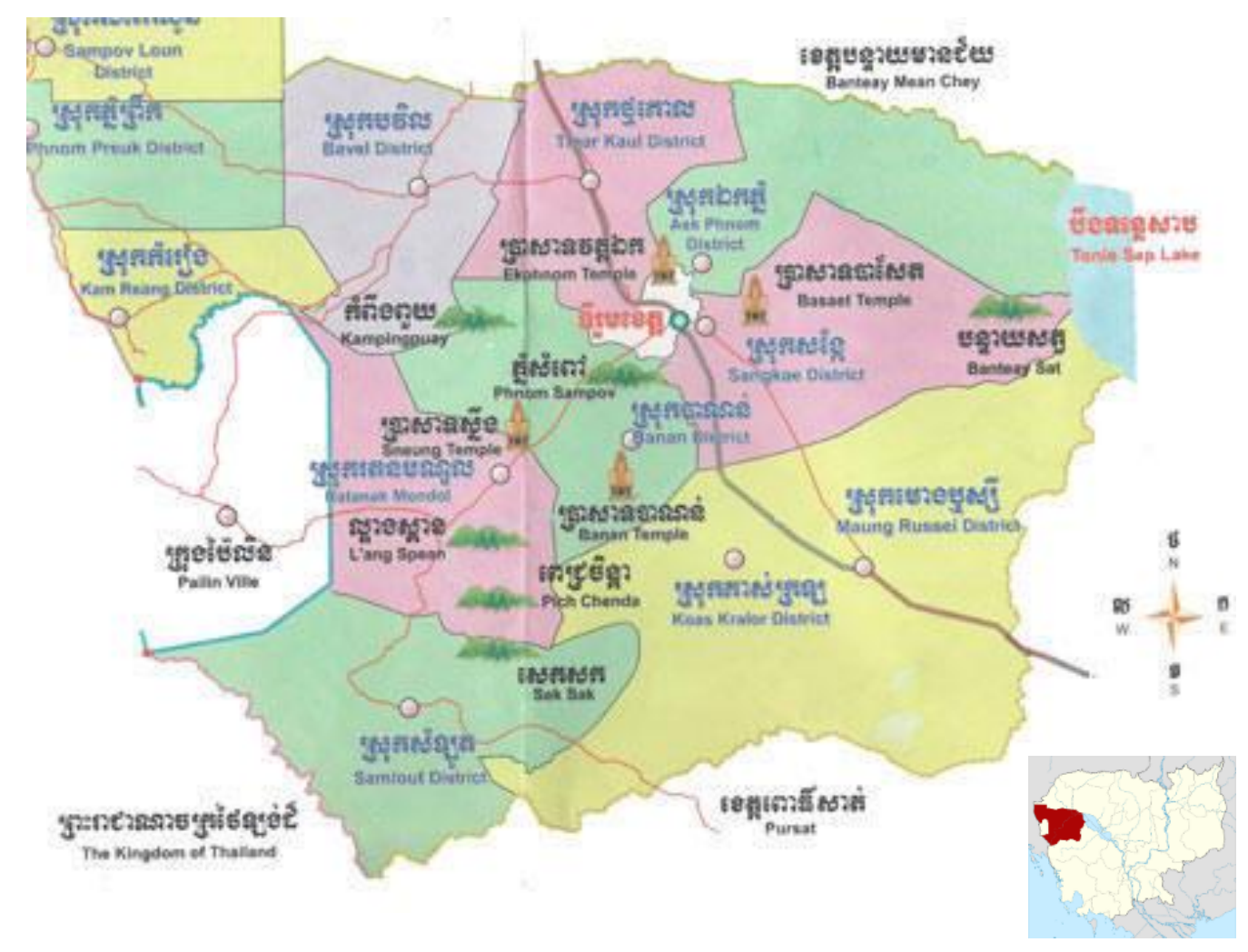

Figure 2. Map of Battambang province 
Table 3. Demography of Battambang province from 2011 to 2015

\begin{tabular}{cccccc}
\hline Description & $\mathbf{2 0 1 1}$ & $\mathbf{2 0 1 2}$ & $\mathbf{2 0 1 3}$ & $\mathbf{2 0 1 4}$ & $\mathbf{2 0 1 5}$ \\
\hline Total population (person) & $1,093,793$ & $1,120,907$ & $1,155,038$ & $1,173,414$ & $1,205,050$ \\
Annual growth rate (\%) & 1.50 & 2.48 & 3.04 & 1.59 & 2.53 \\
Total male population & 540,570 & 555,501 & 569,947 & 584,690 & 602,056 \\
Total female population & 553,223 & 565,406 & 585,091 & 588,724 & 602,994 \\
Female-male ratio & 102.34 & 101.78 & 102.66 & 100.69 & 100.16 \\
Total household & 226,764 & 234,940 & 241,081 & 246,376 & 258,682 \\
Household with female leader (\%) & 14.35 & 14.35 & 14.25 & 14.08 & 13.53 \\
Average family size (person/HH) & 4.82 & 4.77 & 4.79 & 4.76 & 4.66 \\
0-17 years old population & 438,347 & 443,034 & 458,879 & 461,592 & 467,558 \\
\% of 0-17 years old population & 40.08 & 39.52 & 39.73 & 39.34 & 38.80 \\
18-60 years old population & 563,165 & 574,119 & 588,737 & 613,723 & 631,962 \\
\% of 18-60 years old population & 51.49 & 51.22 & 50.97 & 52.30 & 52.44 \\
Over 60 years old population & 92,281 & 103,754 & 107,422 & 98,099 & 105,530 \\
\% of Over 60 years old population & 8.44 & 9.26 & 9.30 & 8.36 & 8.76 \\
\hline Source: Battambang Provincial Profile 2015 and 2016 [36, 37] &
\end{tabular}

Percentage of population work in agriculture in Battambang province between 2012 and 2015 has been decreased gradually from $78.4 \%$ (of total adult population, age between 18 and 60 years old, having primary occupation) in 2012 to $74.8 \%$ in 2015. As being showed in Table 4, rice production and short-term crops cultivation played as two main components of agricultural sectors which provided works for almost 70\% of population (work in agriculture) between 2012 and 2015 . Furthermore, within the period of 2012-2015 the district of Moung Russei was the district with highest population working in rice production (existing of almost 40 thousand of rice farmers) among all 14 districts of Battambang province, following by Thmar Koul and Sangkhae district.

Table 4. Percentage of population work in agriculture in Battambang province 2012-2015

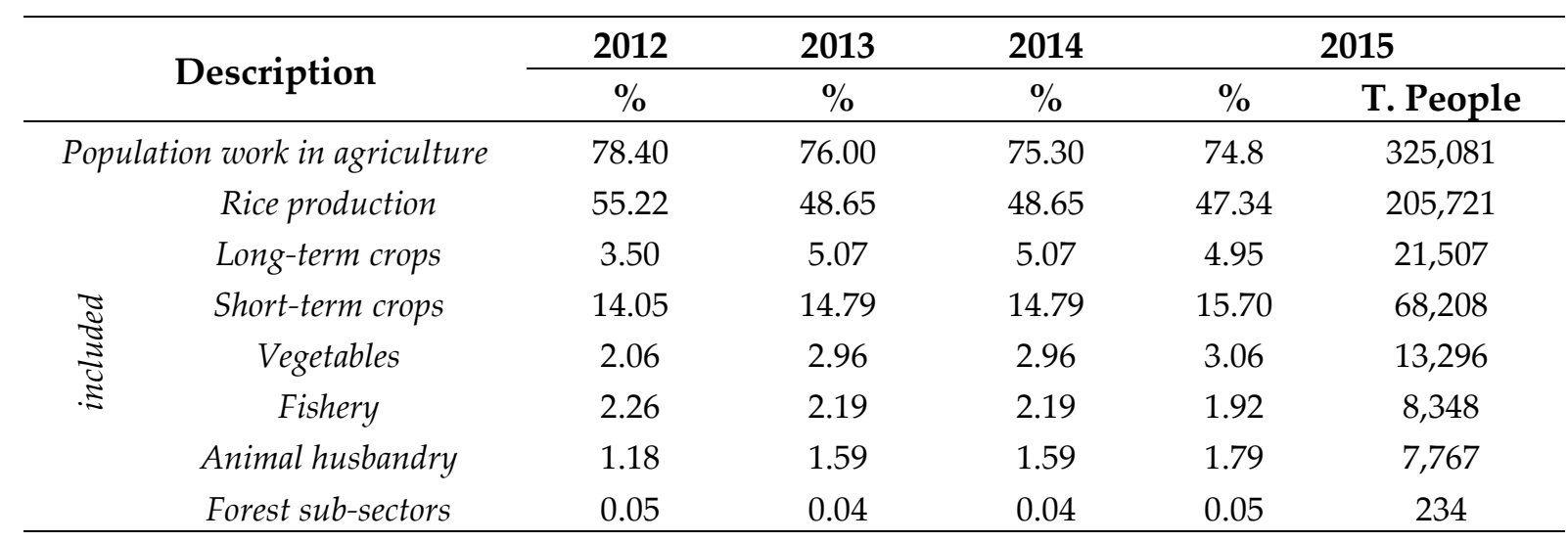

Source: Battambang Provincial Profile 2015 and 2016 [36, 37], “T. People” = Total People

Table 5 reveals the status of rice production in Battambang province as whole between 2012 and 2015. Rice production in Cambodia was categorized into four categories according to the season and place of growing, i.e. wet-season rice, dry-season rice, intensive rice, and up-land rice. Total harvested area, which is the total of harvested area of all this four rice categories, increased by $3.8 \%$ from 2012 to 2013, but decreased by 7.6\% from 2013 to 2014. Nevertheless, although drought have been occurred during the dry season of 2015, total harvested area still improved greatly in 2015 (25\% between 2014 and 2015) due to great incensement of the percentage of wet season rice area actual cultivated (34\% increased from $64 \%$ in 2014 to almost $86 \%$ in 2015). Total rice output quantity increased by only $0.1 \%$ from 2012 to 2013 , but decreased tightly by $20.1 \%$ from 2013 to 2014 which reduced the rice yield from 2.1 tons/ha to only 1.8 tons/ha in 2014. In the year of 2015, due to the 
unfavorable weather condition, rice yield still continued to be lower at 1.7 tons/ha although total provincial rice output quantity increased to almost 912 thousand tons. Table 5 also reveals that in 2015 Battambang had lower rice production yield (compared to 2012) not only in wet-season rice cultivation but also in intensive rice and up-land rice production as well as dry season rice cultivation. Furthermore, between this 4-years period, percentage of wet-season rice area actual cultivated was only $74.7 \%$ in average, while percentage of dry-season rice area actual cultivated was $76.9 \%$ (in average), indicated that rice farmers in Battambang still not yet fully utilized their available land resources within the provincial territory. This means that actual rice cultivated area could have enlarged by further $23 \%$ to $26 \%$. Among all the four rice categories, intensive rice produced the highest yield with the value of 5.14 tons/ha in average between 2012 and 2015 . However, the total harvested area of intensive rice in average accounted for only $15 \%$ of the total harvested area between this 4-years period, which was a very tiny percentage.

Table 5. Situation of rice production in Battambang province between 2012 and 2015

\begin{tabular}{|c|c|c|c|c|}
\hline Description & 2012 & 2013 & 2014 & 2015 \\
\hline Total harvested area (ha) & $442,488.00$ & $459,378.10$ & $424,470.30$ & $529,239.6$ \\
\hline Total output quantity (tons) & $945,336.60$ & $946,297.10$ & $756,431.30$ & $911,805.6$ \\
\hline Rice yield (tons/ha) & 2.10 & 2.10 & 1.80 & 1.7 \\
\hline Income of rice production per capita (USD) & 181.10 & 173.50 & 133.60 & 158.5 \\
\hline Dry season rice available cultivated area (ha) & $31,450.00$ & $33,140.00$ & $32,785.00$ & $33,735.00$ \\
\hline$\%$ dry season rice area actual cultivated & 73.15 & 75.78 & 77.11 & 81.42 \\
\hline Dry season rice yield (tons/ha) & 2.69 & 2.82 & 2.81 & 2.59 \\
\hline Dry season rice quantity (tons) & $61,970.34$ & $70,803.30$ & $71,043.82$ & $71,162.42$ \\
\hline Wet season rice available cultivated area $(h a)$ & $470,258.00$ & $465,350.00$ & $459,067.00$ & 480,658 \\
\hline$\%$ wet season rice area actual cultivated & 71.21 & 77.43 & 64.07 & 85.95 \\
\hline Wet season rice yield (tons/ha) & 2.16 & 2.05 & 1.86 & 1.90 \\
\hline Wet season rice quantity (tons) & $724,129.26$ & $737,706.16$ & $547,332.55$ & $783,005.93$ \\
\hline Intensive rice harvested area $(\mathrm{ha})$ & $49,900.00$ & $65,358.00$ & $84,664.00$ & 84,933 \\
\hline Intensive rice yield (tons/ha) & 5.57 & 5.22 & 4.85 & 4.93 \\
\hline Intensive rice quantity (tons) & $138,000.80$ & $164,047.19$ & $199,724.13$ & $203,253.29$ \\
\hline Up-land rice harvested area (ha) & $34,700.00$ & $8,591.00$ & $20,415.00$ & $3,733.00$ \\
\hline Up-land rice yield (tons/ha) & 2.60 & 2.57 & 1.95 & 1.87 \\
\hline Up-land rice quantity (tons) & $90,157.58$ & $22,038.39$ & $39,848.14$ & $6,994.19$ \\
\hline Average rice output per capita ( $\mathrm{kg} / \mathrm{person})$ & 904.85 & 861.09 & 731.16 & 883.30 \\
\hline Average rice price (Riels/kg) & 859.06 & 847.32 & 829.28 & 837.83 \\
\hline Average highest rice price (Riels/kg) & 970.84 & 970.07 & 941.12 & 951.14 \\
\hline Average lowest rice price (Riels/kg) & 747.28 & 724.58 & 717.43 & 724.52 \\
\hline
\end{tabular}

Source: Battambang Provincial Profile 2015 and 2016 [36, 37]

\subsection{Estimation of SFA Model}

In the stochastic frontier production function (i.e. SFA model), a test whether there is technical inefficiency exist or not can be conducted by testing the null hypothesis $\mathrm{H}_{0}: \gamma=0$, versus alternate hypothesis $\mathrm{H}_{1}: \gamma \neq 0$. Coelli [31] argued that Maximum-Likelihood (ML) shall be estimated by the calculation of the critical value for one-sided likelihood ratio (LR) test. The critical value for a test of size $\alpha$ is equal to the critical value of the $x^{2}$ distribution for a standard test of size $2 \alpha$. Thus, one-sided likelihood ratio test has suitable range, where $H_{0}$ is rejected when $L R \geq x^{2}(2 \alpha)$ for a test of size $\alpha$. At $\alpha=1 \%$ significant level, $x^{2}(2 \alpha)$ has value of 100.62. In SFA model of the present study, however, LR test of the one-sided error has value of 171.80, which is bigger than $x^{2}(2 \alpha)$. Therefore, the null hypothesis, $\mathrm{H}_{0}: \gamma=0$, was rejected, indicates that the existent of TE effect in the model. 
Table 6 lists parameters estimation results by implementing the Maximum-Likelihood estimation method in FRONTIER version 4.1c econometrics software of Coelli [22]. The variance ratio parameter, gamma $(\gamma)$, had a value of 1.00 significant at $\alpha=1 \%$, shows that the variation of the composite error term, was mainly from the technical efficiency $\left(u_{i}\right)$ almost $100 \%$, and the variation of random error $\left(\mathrm{v}_{i}\right)$ less than $1 \%$, indicated that the efficiency of households' rice production in study area between 2013 and 2015 mainly comes from the technical efficiency of the production.

Almost all estimated coefficients have the expected signs. As being showed in Table 6, land input i.e. total household's annual harvested land had positive coefficient and significant at $\alpha=1 \%$, while fertilizer and pesticide input both had positive coefficients but significant at $\alpha=5 \%$, indicates positive contribution of these three input variables to household rice output. These results designated that enlarging the area of harvested land, increasing quantity used of fertilizer, and pesticide input, could cause the increasing of household rice output. Furthermore, with the estimated coefficient of 0.83 , total area (both in wet season and dry season) of rice actually harvested within the year was the main input factor driving extra output for household's rice production compared to fertilizer and pesticide (input). This means farmers who cultivate additional lands have the ability to maintain reasonable levels of the necessary inputs; otherwise, additional area does not increase rice production output if the levels of inputs are not maintained. Yu and Diao [8], Smith and Hornbuckle [38] and some researches of Asian Development Bank [5, 39] also have similar results. Area of cultivated land can be increased by expanding irrigation that permits multiple season cropping. Despite the importance of rice farming in the Cambodian landscape, it has traditionally been dependent on rainfall. Rice is predominately grown in the wet season which produces $80 \%$ of the total crop, and irrigation is mainly used for dry season rice and to complete wet season rice if necessary. Furthermore, it is also an essential component to ensure that farmers can crop during the dry season, and helps to better regulate water inputs which is essential for improved yields [38, 40]. Production efficiency, nevertheless, is constrained by low rates of irrigation [5]. Most Cambodian farmers are able to cultivate rice only once in a year because of inadequate irrigation system and good water management practices. Lack of water during dry season rice farming is significantly constraint and has occasionally caused conflict among farmers [41]. Yu and Diao [8] argued that Cambodia has a huge potential to increase rice production since it is known for its abundant agricultural land and water resources. Such natural resource potential has been underutilized: less than $30 \%$ of potential arable land is under cultivation, and a much smaller portion of area suitable for irrigation is actually irrigated. Thus, expansion of farmland area and irrigation development can be a straightforward way to increase rice production (which is similar to the situation in other developing countries like India [30]).

In addition to farmland area expansion and irrigation development, rice yield can also substantially be increased through crop intensification techniques including both increased use of fertilizer and better farming practices such as those identified under the System of Rice Intensification $\left(S R I^{4}\right)$. Increase use of fertilizers and pesticides are the main characteristics of the Green Revolution in rice agriculture, which spread throughout the Southeast and East Asia during the past 30 years, could increase productivity of rice [5, 38-40]. This is undoubtedly supported by the sturdy significant of fertilizer and pesticide input variables in the SFA model of the current study.

Most developing countries have an unused labor surplus i.e. simple, low-cost, labor-extensive, and low-yielding agricultural production [40]. In general case, workers drop out of agriculture only if they are assured that they can purchase food at attractive prices. If food is not imported in greater amounts, workers remaining in agriculture will have to maintain or increase agricultural

\footnotetext{
${ }_{4}^{4}$ System of Rice Intensification (SRI) was introduced by Ministry of Agriculture, Forestry and Fisheries (MAFF) of Cambodia with the support of CEDAC (Cambodian Center for Study and Development in Agriculture: Centre d'Etude et de Dévelopment Agricole Cambodgien). Under SRI, various rice cultivation techniques with less utilization of modern inputs and inexpensive method of planting in relatively dry area could result in an average yield of 3.6 ton/ha, while under a similar situation the yield with traditional farming practice is only 2.4 ton/ha 42 . CEDAC, Report on the Progress of System of Rice Intensification in Cambodia 2007. 2008, Cambodian Center for Study and Development in Agriculture (Centre d'Etude et de Dévelopment Agricole Cambodgien): Phnom Penh, Cambodia..
} 
production, to produce the food surplus for the non-agricultural workers in exchange for non-agricultural goods and services. Labor input tends to have a positive effect on output yield for small farmers; which is in the contrast view to large-scale (or commercial) farmers in the picture of improvement of mechanization. Nonetheless, labor input of the SFA model in the present study has negative coefficient but not significant at any $\alpha$ level, reveals that there was no any significant relationship between labor input and household rice output in the three districts of Battambang province during the study period. Furthermore, the present case study also established no significant relationship between household rice output and level of other capital investment by household in rice production.

Table 6. Parameters estimated for the SFA model

\begin{tabular}{cccc}
\hline Variables & Coefficient & Standard Error & t-ratio \\
\hline Constant & $8.2818^{* * *}$ & 1.0064 & 8.2288 \\
Ln(Land) & $0.8276^{* * *}$ & 0.2232 & 3.7085 \\
Ln(Labor) & -0.0485 & 0.2297 & -0.2112 \\
Ln(Fertilizer $)$ & $0.0945^{* *}$ & 0.0402 & 2.3490 \\
Ln(Pesticide) & $0.0694^{* *}$ & 0.0339 & 2.0494 \\
Ln(Capital) & 0.0323 & 0.1892 & 0.1708 \\
$t$ & 0.1083 & 0.0971 & 1.1152 \\
Land $x$ Labor & 0.0341 & 0.0433 & 0.7876 \\
Land $x$ Fertilizer & -0.0248 & 0.0210 & -1.1796 \\
Land $x$ Pesticide & 0.0089 & 0.0189 & 0.4701 \\
Land $x$ Capital & -0.0054 & 0.0269 & -0.1992 \\
Labor $x$ Capital & -0.0034 & 0.0425 & -0.0801 \\
$t . t$ & -0.0163 & 0.0248 & -0.6570 \\
$\gamma$ & $1.0000^{* * *}$ & 0.0994 & 10.0565 \\
$\sigma^{2}$ & $0.0993^{* * *}$ & 0.0047 & 20.9696 \\
\hline & log likelihood function & & -235.2186 \\
& LR test of the one-sided error & & 171.8042 \\
\hline
\end{tabular}

Source: Estimated by FRONTIER 4.1c. ${ }^{*}$ indicates significant at $10 \%,{ }^{* *}$ at $5 \%$, and ${ }^{* * *}$ at $1 \%$.

Table 7 illustrates the input elasticity of household's rice production in Battambang province of Cambodia between 2013 and 2015. From this table, it is clearly demonstrated that all inputs, except labor, have had the increasing return to scale to household rice output. Land input had the highest elasticity value among entire input factors, following by pesticide and fertilizer input. Elasticity of actual harvested land of household rice production had the value of 0.83 in average during the study period, indicating that $1 \%$ increase of harvested land (of rice) could cause household rice output to increase by $83 \%$. Similarly, with the elasticity value of 0.083 and 0.056 (in average) respectively of pesticide and fertilizer inputs, revealing that $1 \%$ increase in these two inputs could cause the increasing of household rice output by $8.3 \%$ and $5.6 \%$ respectively. The elasticity of other capital input, on the other hand, had the value of 0.0086 in average, showing that $1 \%$ increasing in capital investment to agricultural machineries (such as walking tractors or koryons, tractors, pumping machine, etc.) as well as other rentals for rice production could also cause the increasing of household rice output (by $0.86 \%$ ).

The negative input elasticity of labor are not only explained the overused of labors for household's rice production but also showing the inefficiency performance of existing labors in the rice fields. Although labor input were not significantly affecting the household rice output in the current study, its negative coefficient sign in the SFA model (previously presented in Table 6) also clearly revealed the over and inefficient used of labor forces. Therefore, additional special strategies or regulations might be needed for snowballing efficiency of rice production's existing labor forces, 
in the purpose of improving Cambodian rice production for sustainability social development as large.

Table 7. Input elasticity of household's rice production in Battambang province, 2013 to 2015

\begin{tabular}{cccccc}
\hline Year & Ln(Land) & Ln(Labor) & Ln(Fertilizer) & Ln(Pesticide) & Ln(Capital) \\
\hline 2013 & 0.8259 & -0.0175 & 0.0562 & 0.0831 & 0.0087 \\
2014 & 0.8256 & -0.0171 & 0.0559 & 0.0833 & 0.0085 \\
2015 & 0.8253 & -0.0169 & 0.0559 & 0.0833 & 0.0086 \\
\hline
\end{tabular}

Source: Calculated by Ms. Excel 2016.

\subsection{Technical Efficiency of Household's Rice Production}

The technical efficiency (TE) and technical efficiency change (TEC) between 2013-2014 and 2013-2015 of household's rice production is being showed in Table 8, categorized by districts and communes. The findings revealed that the overall mean technical efficiency of rice production is estimated at 0.34 (ranged from 0.097 to 0.913 ) which indicated that households in the study areas produce $34 \%$ of rice at best practice at the current level of production inputs and technology. In other words, household rice output could have been increased further by $66 \%$ at same levels of inputs if farmers had been technically efficient. As being showed in Table 8, all rice production households in Battambang produce $35.2 \%$ of rice at best practice in 2013. In 2015, however, due to affecting of the natural disasters (particularly drought during the dry season of 2015 that affected rice production of Cambodia nationwide) and other influencing factors (will be discussed in further details in the next section), the TE of household's rice production in the selected districts of Battambang province had been decreased gradually from 0.352 (in 2013) to 0.302 in 2015 (decreased by 14.3\% between this three-years), indicating that in 2015 rice farmers produced only $30.2 \%$ of rice at best practice at their existing inputs level and technology. Thus, there is still a huge gap for improving rice productivity in the high potential province of rice production like Battambang, since household rice output of rice farmers in this province still have been able to increased further by almost $70 \%$ at the current levels of inputs (in case the farmers had been technically efficient).

Table 8. Technical efficiency (TE) and technical efficiency change (TEC) of household's rice production in Battambang province of Cambodia, from 2013 to 2015

\begin{tabular}{ccccccccc}
\hline \multirow{2}{*}{ District } & \multicolumn{2}{c}{$\mathbf{2 0 1 3}$} & \multicolumn{2}{c}{$\mathbf{2 0 1 4}$} & \multicolumn{2}{c}{ 2015 } & \multicolumn{2}{c}{ TEC (\%) } \\
\cline { 2 - 8 } & Mean & S.E. & Mean & S.E. & Mean & S.E. & $\mathbf{1 3 - 1 4}$ & $\mathbf{1 3 - 1 5}$ \\
\hline Moung Russei & $\mathbf{0 . 3 2 6 7}$ & $\mathbf{0 . 0 1}$ & $\mathbf{0 . 3 3 6 4}$ & $\mathbf{0 . 0 1}$ & $\mathbf{0 . 2 3 9 6}$ & $\mathbf{0 . 0 1}$ & $\mathbf{2 . 9 8}$ & $\mathbf{- 2 6 . 6 6}$ \\
Moung & 0.3056 & 0.02 & 0.3086 & 0.02 & 0.2054 & 0.01 & 0.98 & -32.79 \\
Prey Svay & 0.3503 & 0.01 & 0.3614 & 0.01 & 0.2673 & 0.01 & 3.17 & -23.70 \\
Ruessei Krang & 0.3287 & 0.02 & 0.3238 & 0.02 & 0.2502 & 0.02 & -1.49 & -23.89 \\
Kakaoh & 0.3220 & 0.01 & 0.3517 & 0.01 & 0.2354 & 0.01 & 9.21 & -26.89 \\
\hline Thmar Koul & $\mathbf{0 . 3 5 5 0}$ & $\mathbf{0 . 0 1}$ & $\mathbf{0 . 3 4 1 5}$ & $\mathbf{0 . 0 1}$ & $\mathbf{0 . 2 9 7 1}$ & $\mathbf{0 . 0 1}$ & $\mathbf{- 3 . 8 0}$ & $\mathbf{- 1 6 . 3 1}$ \\
Anlong Run & 0.3273 & 0.02 & 0.3296 & 0.02 & 0.2808 & 0.02 & 0.72 & -14.20 \\
Ta Meun & 0.3528 & 0.02 & 0.3291 & 0.02 & 0.2857 & 0.02 & -6.70 & -19.01 \\
Boeng Pring & 0.3840 & 0.02 & 0.3651 & 0.02 & 0.3239 & 0.02 & -4.94 & -15.66 \\
\hline Sangkhae & $\mathbf{0 . 3 8 2 7}$ & $\mathbf{0 . 0 2}$ & $\mathbf{0 . 3 8 6 5}$ & $\mathbf{0 . 0 2}$ & $\mathbf{0 . 3 8 9 0}$ & $\mathbf{0 . 0 2}$ & $\mathbf{1 . 0 0}$ & $\mathbf{1 . 6 5}$ \\
Ta Pon & 0.3370 & 0.03 & 0.3407 & 0.02 & 0.3338 & 0.02 & 1.10 & -0.94 \\
Kampong Preah & 0.3067 & 0.02 & 0.3205 & 0.02 & 0.3359 & 0.02 & 4.51 & 9.53 \\
Reang Kesei & 0.5044 & 0.03 & 0.4983 & 0.03 & 0.4973 & 0.03 & -1.21 & -1.41 \\
\hline All households & $\mathbf{0 . 3 5 2 0}$ & $\mathbf{0 . 0 1}$ & $\mathbf{0 . 3 5 2 9}$ & $\mathbf{0 . 0 1}$ & $\mathbf{0 . 3 0 1 6}$ & $\mathbf{0 . 0 1}$ & $\mathbf{0 . 2 7}$ & $\mathbf{- 1 4 . 3 0}$ \\
\hline
\end{tabular}

Source: Estimated by FRONTIER 4.1. "S.E." = Standard Error; “TEC" = Technical Efficiency Change; "13-14" = TEC between 2013 and 2014; “2013-2015” = TEC between 2013 and 2015 
Sangkhae district had the highest TE score among three selected districts in all years of the study period (2013, 2014 and 2015). In 2013, rice farmers in Sangkhae district produced $38.2 \%$ of rice at best practice (at the current level of production inputs and technology), while farmers in Thmar Koul and Moung Russei district produced only $35.5 \%$ and $32.7 \%$ of rice (at best practice) respectively. In 2015, rice farmers in Sangkhae district continued to be able to utilize their resources in rice production more efficiently than farmers in the other two districts, by produced almost $40 \%$ of rice at best practice, while the rice production of farmers in Thmar Koul and Moung Russei district became worse, in which respectively produced only $29.7 \%$ and $24 \%$ of rice.

Between 2013 and 2014, TE score of farmers' rice production in Moung Russei district increased by $2.98 \%$ from 0.327 to 0.336 , claimed as the highest increasing percentage among three districts (between this two-years). Nonetheless, in 2015, the TE of household's rice production in this district declined sharply to 0.24 (diminished by 27\% between 2013-2015, and also the highest declining percentage among three districts). However, during the study period, farmers' rice production in Thmar Koul district had the decreasing trend of TE score from 0.355 in 2013 to 0.342 in 2014, then continued to decrease to 0.297 in 2015 (decreased by 16.3\% between 2013-2015). Additionally, in contrast with the situation in Thmar Koul district, household's rice production of farmers in Sangkhae district had the increasing trend of TE score from 0.383 in 2013 to 0.387 in 2014, and still continued to increase to 0.389 in 2015 (1.65\% increased between 2013 and 2015). These statistics are not only reveal that farmers in Thmar Koul and Moung Russei district were more vulnerable to the natural disasters (like flood in 2014's wet season and drought in 2015's dry season for instance) than farmers living in Sangkhae district, but also indicate the abilities of resources utilization in rice production more efficiently than farmers in the other two districts by rice farmers in Sangkhae district.

At the commune-level, the statistical results reveal that the production of rice of farmers' household in Reang Kesei commune had the highest TE score among all communes in Sangkhae district during the study period by producing around $50 \%$ of rice at the best practice of its current inputs level and technology. Farmers' rice production in Thmar Koul district, on the other hand, the commune that have had the highest TE score in all years between 2013 and 2015 was Boeng Pring commune, which produced around $26-36 \%$ at the best practice during this three-years. Likewise, the production of rice in Prey Svay commune of Moung Russei district was also the commune production with the highest TE score in the district, by producing $26-35 \%$ at best practice (at the existing level of inputs and technology).

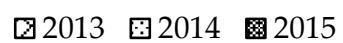

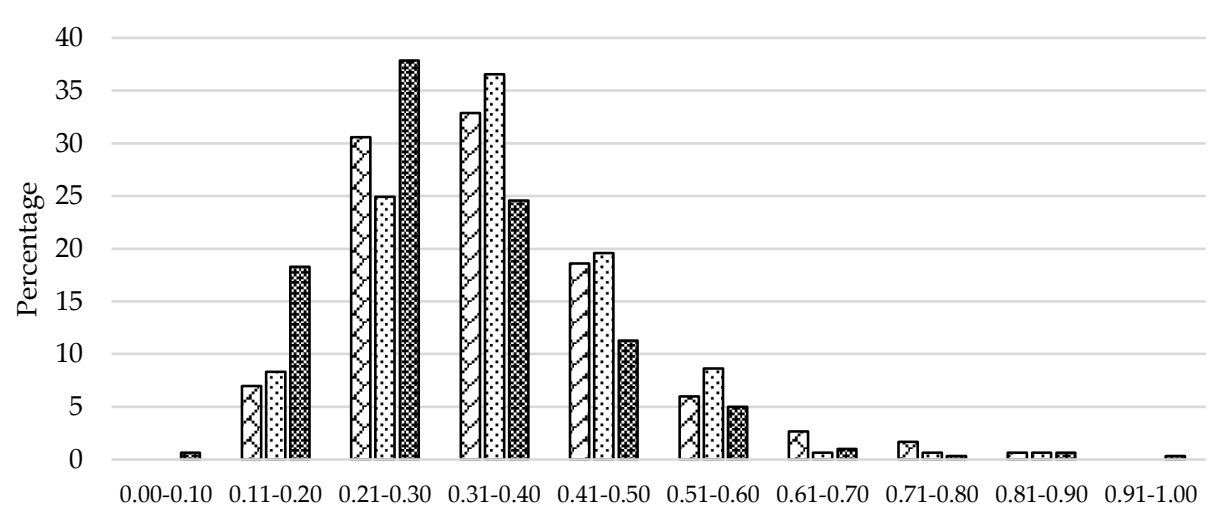

Efficiency level

Figure 3. Technical efficiency distribution of household's rice production in Battambang, 2013-2015

Figure 3 illustrates the distribution of technical efficiency (TE) of Cambodian household's rice production in Battambang province from 2013 to 2015. The study indicates that individual household's TE ranged from a low of $12.6 \%$ to a high of $82.5 \%$ with a mean technical efficiency of 
$35.2 \%$ in 2013 , while in 2014, household's TE ranged from a low of $14.6 \%$ to a high of $86.7 \%$ with a mean technical efficiency of $35.3 \%$ (increased by $0.27 \%$ ). TE of household's rice production in 2015 , on the other hand, ranged from a low of $9.7 \%$ to a high of $91.3 \%$ with a mean technical efficiency of $30.2 \%$ (decreased by 14.3\% in average between 2013 and 2015). Thus, rice production of farmers in Battambang performed better during 2013 and 2014 than in 2015, for which around 33-37\% of households had TE score between 0.31-0.40 compared to 2015 that had only $25 \%$ (due to affecting of drought). However, in 2015, most households had the TE score between 0.21-0.30 (accounted for almost 38\%). These percentages indicated a huge gap (between 62-75\%) of rice farmers in Battambang to increase their production using the current levels of inputs and technologies.

\subsection{Technical Inefficiency Model and Affecting Factors}

The Maximum-Likelihood ( $M L$ ) estimates coefficients of the explanatory variables in the model for the technical inefficiency (TI) of household's rice production in Battambang province, and these TI estimated coefficients are of interest and have implication as shown in Table 9. A negative sign on a parameter explaining the positive effect of the variable on TE (negative impact on the technical inefficiency TI), which means that the variable is improving TE; while for a positive sign, the reverse is true. The results indicated that the sex of household's head, the education level of household's head, family size, the cultivated area of other crops (beside rice), percentage of rice cultivated area benefited from irrigation systems, number of plot area, and disasters (droughts, floods, insects) are significant determinants of the technical efficiency in the Cambodian rice production.

As being showed in Table 9, it is noticeable that the variable of disaster and other crops' cultivated area both had positive coefficient signs (positive impact on the TI)and were significant at $1 \%$, while education of household head and family size also had positive coefficient signs but significant at $10 \%$, indicating negative relationships of these factors to TE of household's rice production, means that these factors are decreasing TE. With the highest coefficient of 0.27 , disaster was the core influencing factor leads to decreasing TE of household's rice production, while the education of household head and family size are the second and the third factors with the estimated coefficient value of 0.03 and 0.01 respectively. These results indicate that $1 \%$ increasing in disaster, education of household head and family size will cause the decreasing of TE by $27 \%, 3 \%$ and $1 \%$ respectively. The impact of education level of household's head is negatively significant on the efficiency (TE) of household's rice production, implying that less educated rice farmers are more efficient than better educated farmers. It means being an educated rice farmer was not enough to significantly attain greater levels of efficiency. This result, thus, is consistent with the finding of Balde, Kobayashi [20], who found that education level was significant and negatively affecting the TE of Mangrove rice production in the Guinean coastal area. Additionally, Kabir, Musharraf [25] who estimate the impact of bio-slurry to Boro rice production in Bangladesh, also found the same negative sign of coefficient of education relation to production inefficiency of rice. Besides, the variable of family size also has a negative and significant impact (on TE). This result implies that farmers with fewer family members seem to perform better than those with more members. Furthermore, the negatively significant of other crops' cultivated area variable, indicating that reducing rice's cultivated area for growing other crops beside rice like corn, sugarcane, cassava, cucumber, pepper, wax melon, bitter melon, bean, eggplant, and other vegetables, etc. might cause the TE of household's rice production to decrease. However, the value of this variable's coefficient is quite tiny, reflecting the very little effect of other crops' cultivated area on TE.

The variable of irrigated area had negative coefficient sign (negative impact on the TI)and significant at $1 \%$, while number of plot area and the sex of household head also had negative coefficient signs but significant at $5 \%$, indicating the positive impact of these factors on TE of household's rice production, means that these factors are increasing TE. With the similar estimated coefficient value of 0.07, number of plot area and the sex of household head are the two core factors increasing TE of rice production at household-level, signposted that $1 \%$ increase in these factors could cause the TE to increase by $7 \%$ respectively. The key messages from this finding are that farmers who cultivated on additional plot lands might have extra opportunities to obtain further benefits from their rice 
production. This could be explained in some ways. For example, farmers who cultivated two or more plot lands, sometimes one of his plot lands affected by natural disasters (droughts, floods, or insects) while the other (of his plot lands) not. Thus, he still be able to gain output of rice production from the plot(s) that did not affected by disasters. Likewise, the similar reason might be able to apply to the plot land that benefiting from irrigation systems as well. For the farmers cultivated more than one plot land, sometimes one of his plot lands does not benefit or located near irrigation systems or water sources such as rivers, lakes, or ponds (that cannot be cultivated during dry season) while his other plot land located near water sources (or benefiting from irrigation systems) which allow him to expand his production by expanding the annual cultivated area through dry season cultivation on plot land that benefiting from irrigation systems. These could be the benefits of cultivating on more plot lands compared to farmers who cultivated on only one plot land. The positively significant of sex of household head on TE of household's rice production, on the other hand, is not only explain the imperative roles of female in rice production and family management, but also reveals the limited abilities of existing male household's head as well as inefficiency used of male labors in their household's rice production. Thus, some further extraordinary strategies or procedures might also need to be put in place to enhance the efficiency of labor utilization and allocation.

Table 9. Rice production technical inefficiency model parameters

\begin{tabular}{cccc}
\hline Variables & Coefficient & Standard Error & t-ratio \\
\hline Constant & $1.3048^{* * *}$ & 0.2213 & 5.8954 \\
Household head's age (years old) & 0.0007 & 0.0010 & 0.6266 \\
Household head's Sex (0:male/1:female) & $-0.0657^{* *}$ & 0.0327 & -2.0097 \\
Household head's education & $0.0295^{*}$ & 0.0159 & 1.8614 \\
Family size (total family members) & $0.0123^{*}$ & 0.0070 & 1.7672 \\
Female labor (total females 18-65yr) & 0.0161 & 0.0139 & 1.1639 \\
Other crops' cultivated area & $0.0000^{* * *}$ & 0.0000 & 3.4658 \\
Irrigated area & $-0.0087^{* * *}$ & 0.0017 & -5.2380 \\
Distance to water sources & -0.0264 & 0.0210 & -1.2547 \\
Distance to district & 0.0004 & 0.0017 & 0.2602 \\
Number of plot area & $-0.0678^{* *}$ & 0.0273 & -2.4867 \\
Number of cultivation per year & -0.0581 & 0.1091 & -0.5322 \\
Disaster & $0.2664^{* * *}$ & 0.0344 & 7.7360 \\
\hline
\end{tabular}

Source: Estimated by FRONTIER 4.1. ${ }^{*}$ indicates significant at $10 \%,{ }^{* *}$ at $5 \%$, and ${ }^{* * *}$ at $1 \%$.

Strongly significant of irrigated area variable, which is the percentage of rice production land located near water sources or benefited from irrigation systems (i.e. irrigated rice land) to total annual cultivated land of rice, showing that the greater percentage of irrigated rice land could lead to increasing in TE of household's rice production. This result highlights the important of irrigation systems in Cambodian rice production, particularly in the high potential province for rice production like Battambang. Therefore, focusing on irrigation development and improvement as well as good water management systems are the key factors to increase rice productivity in the northwest region of Cambodia (especially in Battambang province) that might need to be concerned and developed gradually.

\section{Conclusions}

The aim of this study are to measure the technical efficiency (TE) of Cambodian rice farmers in the northwest region (i.e. the region of Tonle Sap plain, the second largest rice production region after Mekong river plain), and to determine its main influencing factors by using the stochastic frontier production function (i.e. SFA model). The study utilized primary data collected from 301 rice farmers in three selected districts of Battambang province (Northwest Cambodia) by structured questionnaires. 
The empirical results indicated that the level of rice production output varied according to the differences in production techniques and differences in the efficiency of the production processes. The mean technical efficiency of rice production in Battambang province is 0.34 (ranged from 0.097 to 0.913 ) which means that famers in this region produce $34 \%$ efficiently rice at best practice at the current level of production inputs and technology, indicates that rice output has the potential of being increased further by $66 \%$ at the same level of inputs if farmers had been technically efficient. Furthermore, during the study periods the technical efficiency of household's rice production recorded a $-14.3 \%$ declining rate which diminished from $35.2 \%$ in 2013 to $30.2 \%$ in 2015 due to highly affected of drought during the dry season of 2015.

Three main conclusions emerged from the study's results. First, based on decomposing the $S F A$ model, increasing harvested land area (particularly in dry season through the development of irrigation facilities, irrigation systems and good water management practices, for gaining benefit from multi-cropping systems) is the major influencing factor of household's rice production of farmers in Battambang province which is the rice bowl of Cambodia, while the increased fertilizers and pesticides application are the second and third influencing factors respectively. These results are not identical surprising, since these are the straightforward techniques for increasing rice productivity in most developing countries. Similarly, this also confirmed the existing problems in Cambodian rice production sector which were previously addressed by relevant studies, such as [5, 8, 39, 41].Second, the calculation of input elasticity reveals that all inputs, except labor, have had the increasing return to scale to household rice output, while land input had the highest elasticity value among entire input factors, following by pesticide and fertilizer input. The negative input elasticity of labor are not only explained the overused of labors for household's rice production but also showing the inefficiency performance of existing labors in the rice fields. Finally, the decomposing of the technical inefficiency (TI) model reveals that the core influencing factors lead to decreasing TE of household's rice production (in Battambang) are disaster (i.e. droughts, floods, and insects), education level of household's head, number of people in the family (i.e. family size) and cultivated area of other crops such as corn, sugarcane, cassava, cucumber, pepper, wax melon, bitter melon, bean, eggplant, and other vegetables. Conversely, the main influencing factors that lead to increasing TE are irrigated area, number of plot area and the sex of household's head.

Acknowledgments: This study was a part of the project "the study on the production factors allocation efficiency and its growth road of south area's household agricultural production under the situation of the new return of collective forestry reform" funded by the China's National Science Foundation (project number: 71273211) and the Northwest A\&F University of China.

Author Contributions: Author contribution to the present study as follow: "Sokvibol Kea and Hua Li conceived and designed the study and survey; Sokvibol Kea performed the survey and gathered the data; Sokvibol Kea and Linvolak Pich analyzed the data; Sokvibol Kea, Hua Li, and Linvolak Pich contributed reagents/materials/analysis tools; finally, Sokvibol Kea wrote the paper."

Conflicts of Interest: The authors declare no conflict of interest.

\section{References}

1. Ahmad, F., Food security in Pakistan. Pakistan Journal of Agricultural Science, 2009. 46(2): p. 83-89.

2. FAOSTAT, FAOSTAT Online Database 2015. 2015, Food and Agriculture Organization of the United Nations.

3. World.Bank. World Bank: Agriculture. 2014 October 10th, 2014 [cited 2015 February, 24th]; Available from: http://www.worldbank.org/en/topic/agriculture.

4. Nesbitt, H.J., Rice Production in Cambodia. 1997: Cambodia-IRRI-Australia Project.

5. ADB, Improving rice production and commercialization in Cambodia. 2014, Asian Development Bank (ADB): Printed in the Philippines.

6. OECD, Structural Policy Country Notes Cambodia, in The Economic Outlook for Southeast Asia, China and India 2014: Beyond the Middle-Income Trap. 2013.

7. CIA. The World Factbook. 2014 June 23, 2014 [cited 2015 January 10]; Available from: https://www.cia.gov/library/publications/the-world-factbook/geos/cb.html. 
8. Yu, B. and X. Diao, Cambodia's Agricultural Strategy: Future Development Options for the Rice Sector. 2011, A policy discussion paper of Cambodia Development Resource Institute (CDRI): Phnom Penh, Cambodia.

9. AFD, Support to the rice sector in Cambodia 2012-2014 project, in Support to Cambodia's rice value-chain. 2011, Agence Française de Développement (AFD).

10. Yu, B. and X. Diao, Cambodia's Agricultural Strategy: Future Development Options for the Rice Sector. 2010, International Food Policy Research Institute: Washington, D.C.

11. World.Bank, Cambodia economic update: Clear skies (English). 2014, World Bank Group.

12. Sawaneh, M., I.A. Latif, and A.M. Abdullah. Total Factor Productivity of Rice Farming in Selected Southest Asian Countries. in the International Conference on Social Science Research, ICSSR 2013. 2013. Penang, Malaysia.

13. Coelli, T.J., et al., An Introduction to Efficiency and Productivity Analysis (Second Edition). 2005, New York, the USA: Springer Science + Business Media, Inc.

14. Coelli, T.J., Recent Developments in Frontier Modeling and Efficiency Measurement. Australian Journal of Agricultural Economics, 1995. 39(3): p. 219-245.

15. Ueasin, N., S.-Y. Liao, and A. Wongchai, The Technical Efficiency of Rice Husk Power Generation in Thailand: Comparing Data Envelopment Analysis and Stochastic Frontier Analysis. Energy Procedia, 2015. 75: p. 2757-2763.

16. Farrell, M.J., The measurement of productive efficiency. Journal of the Royal Statistical Society, 1957. Series A 120(3): p. 253-290.

17. Haryanto, T., B.A. Talib, and N.H.M. Salleh, An Analysis of Technical Efficiency Variation in Indonesian Rice Farming. Journal of Agricultural Science, 2015. 7(9).

18. Hong, N.B. and M. Yabe, Resource Use Efficiency of Tea Production in Vietnam: Using Translog SFA Model. Journal of Agricultural Science, 2015. 7(9).

19. Aigner, D.J., C.A.K. Lovell, and P. Schmidt, Formulation and Estimation of Stochastic Frontier Production Function Models. Journal of Econometrics, 1977. 6(1): p. 21-37.

20. Balde, B.S., et al., An Analysis of Technical Efficiency of Mangrove Rice Production in the Guinean Coastal Area. Journal of Agricultural Science, 2014. 6(8): p. 179-196.

21. Meeusen, W. and J. Van den Broeck, Efficiency Estimation from Cobb-Douglas Production Functions with Composed Error. International Economic Review, 1977. 18(2): p. 435-444.

22. Coelli, T.J., A Guide to FRONTIER Version 4.1: A Computer Program for Stochastic Frontier Production and Cost Function Estimation, ed. N. 7/96. 1996, Armidale, NSW 2351, Australia: University of New England.

23. Battese, G.E. and T.J. Coelli, A Model for Technical Inefficiency Effects in a Stochastic Frontier Production Function for Panel Data. Empirical Economics, 1995. 20: p. 325-332.

24. Heriqbaldi, U., et al., An Analysis of Technical Efficiency of Rice Production in Indonesia. Asian Social Science, 2014. 11(3).

25. Kabir, H., et al., Technical efficiency of Boro rice production in Bangladesh: A case of bio-slurry application. J. Bangladesh Agril. Univ., 2015. 13(1): p. 101-108.

26. Nehal Hasnain, M., Technical Efficiency of Boro Rice Production in Meherpur District of Bangladesh: A Stochastic Frontier Approach. American Journal of Agriculture and Forestry, 2015. 3(2): p. 31.

27. Kea, S., H. Li, and L. Pich, Technical Efficiency and Its Determinants of Rice Production in Cambodia. Economies, 2016. 4(4): p. 22.

28. Shinta, A., et al., Measurement of Technical Efficiency That Involving Farmers Preferences Towards Risk of Rice Farming in Malang (Indonesia). Russian Journal of Agricultural and Socio-Economic Sciences, 2016. 51(3): p. 3-13.

29. Stevenson, R.E., Likelihood Functions for Generalized Stochastic Frontier Estimation. Journal of Econometrics, 1980. 13: p. 57-66.

30. Battese, G.E. and T.J. Coelli, Frontier production functions, technical efficiency and panel data, With application to paddy farmers in India. The Journal of Productivity Analysis, 1992. 3: p. 153-169.

31. Coelli, T., Estimators and hypothesis tests for a stochastic frontier function: A Monte Carlo analysis. The Journal of Productivity Analysis, 1995. 6(3): p. 247-268.

32. Coelli, T.J. and G.E. Battese, Identification of factors which influence the technical inefficiency of Indian farmers. Australian Journal of Agricultural Economics, 1996. 40(2): p. 103-128.

33. Wikipedia. Green Revolution. 2016 September 06, 2016 [cited 2016 September 08]; Available from: https://en.wikipedia.org/wiki/Green_Revolution. 
34. Abedullah, K., S. and K. Mushtaq, Analysis of technical efficiency of rice production in punjab (Pakistan): Implications for future investment strategies. Pakistan Economic and Social Review, 2007. 45(2): p. 231-244.

35. Plubins, R.Q. "Khmer Empire" Ancient History Encyclopedia. 2016 March 12, 2013 [cited 2016 October 8, 2016]; Available from: http://www.ancient.eu/Khmer Empire/.

36. BTB-PDP, Battambang Provincial Profile 2015 (Khmer), B.P.D.o. Planning, Editor. 2015, Battambang Provincial Department of Planning: Battambang, Cambodia.

37. BTB-PDP, Battambang Provincial Profile 2016 (Khmer), B.P.D.o. Planning, Editor. 2016, Battambang Provincial Department of Planning: Battambang, Cambodia.

38. Smith, D. and J. Hornbuckle, A Review of rice productivity in Cambodia and water measurement using direct and indirect methods on a dry season rice crop. 2013, Technical Report to ACIAR, Canberra, CSIRO Sustainable Agriculture Flagship, Australia.

39. ADB, The Rice Situation in Cambodia. 2012, Technical Assistance Consultant's Report of Asian Development Bank (ADB).

40. Eng, P.v.d., Productivity and Comparative Advantage in Rice Agriculture in South-East Asia Since 1870. Asian Economic Journal, 2004. 18(4): p. 345-370.

41. CDRI, Annual Development Review 2011-12. Annual Development Review. 2012, Phnom Penh, Cambodia: Cambodia Development Resource Institute (CDRI).

42. CEDAC, Report on the Progress of System of Rice Intensification in Cambodia 2007. 2008, Cambodian Center for Study and Development in Agriculture (Centre d'Etude et de Dévelopment Agricole Cambodgien): Phnom Penh, Cambodia. 